\title{
Praktik Ekonomi Islam pada Komunitas Keagamaan di Sulawesi Selatan
}

\author{
Mustaqim Pabbajah \\ universitas.teknologiah@uty.ac.id
}

\begin{abstract}
This article aims to explain the implementation of the Islamic economic system in the process and practice of community empowerment by selecting the An-Nadzir religious community in South Sulawesi as the basis for its analysis. In this case An-Nadzir developed as an independent religious community with the application of Islamic economics in social-economic life. This research is done by qualitative data collection, then presented in descriptive analysis. In the era of the ASEAN economic community and the current global economic competition, various forms of strategy and implementation of the economic system need to be done. One is the implementation of Islamic economics with the empowerment of society as a practical offer. This is endeavourmust be implemented through the empowerement the middle to lower community in order to create a strong, creative, and more independent society. The social-economic empowerment of religious communities is one of the bids as an alternative to implementing the Islamic economic system.
\end{abstract}

\begin{abstract}
Abstrak
Artikel ini bertujuan untuk menjelaskan implementasi sistem ekonomi Islam dalam proses dan praktik pemberdayaan masyarakat dengan memilih komunitas keagamaan An-Nadzir di Sulawesi Selatan sebagai basis analisisnya. Dalam hal ini An-Nadzir berkembang sebagai komunitas keagamaan yang mandiri dengan penerapan ekonomi Islam dalam kehidupan ekonomi-sosial. Penelitian ini dilakukan dengan cara pengumpulan data secara kualitatif, kemudian dipaparkan secara deskriptif analisis. Pada era masyarakat ekonomi ASEAN dan persaingan ekonomi global saat ini, berbagai bentuk strategi dan implementasi sistem ekonomi perlu dilakukan. Salah satunya adalah implementasi ekonomi Islam dengan pemberdayaan masyarakat sebagai sebuah tawaran praktis. Hal ini dilakukan melalui pemberdayaan komunitas menengah ke bawah dalam rangka terciptanya masyarakat yang kuat, kreatif, dan lebih mandiri. Pemberdayaan sosial-ekonomi komunitas keagamaan merupakan salah satu tawaran sebagai alternatif pengimplementasian sistem ekonomi Islam.
\end{abstract}

Keywords: Implementasi Ekonomi Islam, Pemberdayaan dan komunitas keagamaan 


\section{A. Pendahuluan}

Implementasi sistem ekonomi Islam di Indonesia dalam beberapa tahun terkahir ini, baik pada wacana teoritis-konseptual (sebagai wacana akademik) maupun pada tataran praktis di tengah masyarakat mengalami peningkatan yang semakin pesat. Upaya implementasi ini tentu saja sangat menggembirakan, karena ini merupakan cerminan dari semakin meningkatnya gairah keberagamaan umat Islam dalam menjalankan syariat. Hal ini sebagai salah satu refleksi dari pemahaman bahwa ekonomi Islam bukan hanya sekedar konsepsi, akan tetapi ia merupakan hasil suatu proses transformasi nilai-nilai Islam yang membentuk kerangka serta perangkat kelembagaan dan pranata ekonomi yang hidup dan berproses dalam kehidupan masyarakat. Adanya konsep pemikiran dan organisasi-organisasi yang dibentuk atas nama sistem ini sudah tentu bisa dinilai sebagai model dan awal pertumbuhan ekonomi Islam.

Indonesia sebagai negara berkembang telah berusaha membangun dan meningkatkan sumber daya masyarakat untuk mengantisipasi kompetisi bebas di era globalisasi. Usaha semacam itu terutama dilandasi oleh kesadaran bahwa dengan adanya sumber daya yang handal akan menghindarkan diri dari ketergantungan ekonomi dan menciptakan masyarakat mandiri. Berbagai upaya telah dilakukan untuk meningkatkan sumber daya tersebut dengan cara pemberdayaan (empowerment) masyarakat, baik di tingkat nasional maupun pada tingkat lokal, mulai dari yang sifatnya individu hingga pemberdayaan secara kolektif. ${ }^{1}$ Upaya ini dilakukan untuk menciptakan masyarakat yang lebih kreatif dan mandiri dalam kehidupan sosial-ekonomi.

Apabila diamati dalam kajian maupun kebijakan dan pelaksanaan pembangunan masyarakat di negara-negara yang sedang berkembang sejak era 1950-an sampai saat ini, perspeketif pembangunan yang menjadi arus utama adalah perspektif pembangunan yang berbasis pada masyarakat. ${ }^{2}$ Dalam implementasi pembangunan berbasis masyarakat tersebut digunakan pendekatan pemberdayaan masyarakat. Pendekatan pemberdayaan digunakan karena diyakini sumber masalah kemiskinan dan keterbelakangan adalah ketidakberdayaan. Kondisi ketidakberdayaan di samping disebabkan karena proses sejarah perkembangan sosial ekonomi negara-negara yang sedang berkembang yang cukup panjang

\footnotetext{
${ }^{1}$ Harry Hikmat. Strategi Pemberdayaan Masyarakat. (Bandung: Humaniora, Utama Press 2010)

${ }^{2}$ Soetomo. Pemberdayaan Masyarakat (Yogyakarta: Pustaka Pelajar, 2011) h. 5
} 
terutama pada periode kolonial, juga disebabkan karena penggunaan pendekatan pembangunan masyarakat menjadi terpusat, sehingga pada tingkat lokal menjadi marjinal.

Permasalahan sosial ekonomi biasanya terjadi akibat dari kebijakan yang diterapkan secara sentralistik atau terpusat. Orientasi pembangunan hanya menekankan pertumbuhan ekonomi makro, kebijakan yang terpusat dan bersifat top down, memposisikan masyarakat sebagai obyek. ${ }^{4}$ Pada kondisi seperti ini, masyarakat tergiring untuk kurang menyadari masalah sosial yang ada dalam lingkungan mereka. Mereka juga kurang mampu memanfaatkan potensi dan sumber daya sosial yang ada untuk menangani masalah sosial ekonomi dari dan oleh masyarakat sendiri. Dalam hal ini, masyarakat berada dalam situasi kerentanan struktural (Structural Vulnerability), ${ }^{5}$ di mana tingkat kemiskinan yang tinggi disertai ketidak setaraan. Ketidakmampuan dalam mengakses terhadap pelayanan dasar hidup seperti pelayanan kesehatan, pelayanan pendidikan dan lain-lain. Hal ini tentunya membuat masyarakat tidak memperoleh kesempatan secara bebas untuk memuaskan aspirasi dan merealisasikan potensi mereka dalam menangani permasalahan sosial-ekonomi yang ada dalam kehidupan. ${ }^{6}$

Dalam kaitannya dengan hal tersebut, tulisan ini mencoba mengkaji implementasi sistem eknomi Islam dengan pendekatan pemberdayaan komunitas keagamaan pada tingkat lokal. Dalam hal ini tulisan ini lebih fokus pada penerapan sistem ekonomi Islam dengan pemberdayaan kelompok secara mandiri. Di sini dibahas bagaimana seharusnya nilai-nilai keislaman secara normatif dipahami oleh kelompok masyarakat, kemudian nilai-nilai tersebut diimplementasikan menjadi prilaku sosial-ekonomi masyarakat tersebut. Oleh karena itu, dalam penelitian ini mengambil studi kasus salah satu komunitas keagamaan di

\footnotetext{
${ }^{3}$ Wrihatnolo, Randy R dan Riant Nugroho Dwidjowito. Manajemen Pemberdayaan: Sebuah Pengantar dan Panduan Untuk Pemberdayaan Masyarakat. (Jakarta: Elex Media Komputindo. 2007)

${ }^{4}$ Sugeng Budiharsono, Strategi Penanggulangan Kemiskinan Nasional, TKP3KPK, Menko Kesra, Jakarta. 2004)

5 Sadji Partoatmodjo, Masalah Kemiskinan dan kompleksitas Penanggulangannya, TKP3KPK Menko Kesra, Jakarta 2004

${ }^{6}$ Harry Hikmat. "Pembangunan Sosial yang Berpusatkan pada Rakyat: Reorientasi Paradigma Pembangunan Kesejahteraan Sosial Pascakrisis". Makalah. (Bandung: Unpad 1999).
} 
Sulawesi Selatan yaitu komunitas An-Nadzir sebagai obyek analisis implementasi sistem ekonomi Islam di tengah masyarakat lokal.

Komunitas An-Nadzir mengembangkan diri sebagai salah satu kelompok masyararakat Islam yang mengembangkan dan memadukan nilai-nilai keislaman klasik (khususnya berupaya meniru kehidupan nabi Muhammad) tanpa harus kehilangan nuansa modernitas. Selain itu, dengan spirit keagamaan yang kental mereka tetap peduli terhadap etos kerja. Berkaitan dengan ini, Weber ${ }^{7}$ menyatakan bahwa agama yang bersemangat modernlah yang akan memberi dorongan dan spririt terhadap pertumbuhan ekonomi. Sedangkan dalam pandangan Turner $^{8}$ bahwa kaitan agama dengan motif-motif dan sikap-sikap dominan, dapat ditemukan pada setiap sektor sosial dari tradisi religius. Di sini dapat terlihat bahwa agama berperan sebagai motivasi kerja dalam

Hal semacam ini, menawarkan peradaban Islam yang tetap berbasis pada "keyakinan agama", bukan ideologi. Dalam hal ini basis keyakinan yang secara terus menerus diijtihadi untuk berhasil menjadi rumusan-rumusan yang berkadar sebagai "ilmu" (logis, konkret, empiris) sebagaimana yang dikemukakan oleh Kuntowijoyo". Jika keberhasilan Cina didasarkan oleh ideologi yang disebut "ekonomi pasar sosialis", sudah tentu bagi umat Islam yang ditawarkan harus lebih daripada sekedar "ideologi", melainkan "ilmu" atau "objektivikasi" Islam yang dikenal sebagai din (dunia-akhirat, keuntungan-pahala, kesejahteraansurga, material-spiritual), bukan sekedar agama dalam arti umum. Maka objektivikasi yang menghasilkan konsep-konsep yang terukur (logis, kongkret, empiris) terhadap istilah-istilah agama Islam, seperti istilah "pahala”, "komunitas", "birr”, "taqwa”, “amanah", dan sebagainya.

Berangkat dari asumsi tersebut, implementasi sistem ekonomi Islam melalui pemberdayaan komunitas telah menjadi fokus utama Komunitas An-Nadzir dalam rangka mendorong komunitas yang kuat dan mandiri. Kemandirian ini sangat penting karena mereka telah memutuskan untuk hidup dengan cara mereka sendiri. Mereka telah mengkonstruksi model keyakinan dan cara beragama yang berbeda dengan masyarakat Islam pada umumnya (di Indonesia). Mereka telah

\footnotetext{
${ }^{7}$ Max Weber. The Protestant Ethic and Spirit of Capitalism. (New York: Charles Scribners, Son 1956) h. 48-49

${ }^{8}$ Brian S Turner. Religion and Social Theory. (London: Sage Publication, 1991) h. 260

9 Kuntowijoyo. Islam sebagai Ilmu, Epistemologi, Metodologi, dan Etika (Jakarta: Penerbit Teraju, 2004) h. 81-83
} 
memutuskan untuk hidup sebagai Komunitas spiritual yang peduli kebutuhan ekonomi warga. Lebih jelasnya, komunitas keagamaan ini kuat sebagai kelompok sosial (civil society) yang tidak menggantungkan hidup pada kekuatan ekonomi luar. Pemberdayaan Komunitas ini patut menjadi acuan untuk kehidupan umat (Islam) yang lebih baik dan mandiri, sebab pemberdayaan semacam ini merupakan proses membangun kembali struktur komunitas insan, di mana cara-cara baru untuk berhubungan antar pribadi, mengorganisasikan kehidupan sosial, ekonomi dan memenuhi kebutuhan insani menjadi lebih dimungkinkan.

Dari uraian di atas menunjukkan bahwa eksistensi Komunitas AnNadzir di Sulawesi Selatan dengan stigma negatif oleh sebagian masyarakat, dengan anggapan masyarakat sebagai komunitas nonmainstream islam, sesat dan perlu pengawasan dan lain sebagainya merupakan hal yang perlu diklarifikasi. Dalam kenyataannya, komunitas An-Nadzir dapat dijadikan sebagai komunitas percontohan dalam pengimplemntasian sistem ekonomi Islam dalam kehidupan sosial secara praktis. Meskipun dari penampilan yang cukup unik dari segi fisik dan aktivitas keagamaan berbeda yaitu, tampilan fisik berambut panjanngh dan dicat merah dengan masyarakat Islam pada umumnya (nonmainstream), akan tetapi mereka memiliki kemampuan dalam memanfaatkan sumber daya kelompok dan sumber daya alam yang dikelolah secara mandiri untuk pemenuhan kebutuhan ekonomi.

Berdasarkan latar belakang masalah tersebut, maka permasalahan yang diangkat dalam penelitian ini, adalah bagaimana implementasi sistem ekonomi Islam yang diterapkan oleh komunitas An-Nadzir? Pemberdayaan apa saja yang dilakukan untuk pengimplementasian sistem ekonomi Islam pada masyarakat di Sulawesi Selatan?

Berdasarkan rumusan masalah tersebut, dalam tulisan diuraikan beberapa tujuan dari penelitian, Pertama untuk mengeksplorasi lebih dalam implemnetasi sistem ekonomi Islam yang dipraktikkan oleh komunitas keagamaan An-Nadzir di Sulawesi Selatan melalui pemberdayaan komunitas. Kedua, memberikan gambaran implementasi sistem ekonomi Islam secara praktis pada masyarakat Sulawesi Selatan pada khususnya, dan masyarakat Indonesia pada umumnya. Untuk

${ }^{10}$ Mustaqim Pabbajah. Pemberdayaan Sosial-Ekonomi sebagai Strategi Penanganan Gerakan Keagamaan pada Kasus Jama'ah An-Nadzir di Kabupaten Gowa Sulawesi Selatan. Jurnal Multikultural dan Multireligius Harmoni Volume 11, Nomor 3, 2012, 24. 
keperluan praktis, penelitian ini menghasilkan deskripsi dan penjelasan tentang aspirasi, persepsi, kehendak, gagasan, cita-cita dan pemikiran tentang tatanan masyarakat yang dilhami oleh spirit keagamaan di Indonesia pada umumnya, dan di Sulawesi Selatan pada khususnya yang juga menjadi obyek penelitian ini. Dengan deskripsi dan penjelasan ini para pengambil kebijakan dapat mengambil manfaat, dan para penganut agama lain dapat memperoleh pengetahuan tentang pandangan, aspirasi dan cita-cita komunitas keagamaan yang pada gilirannya dapat menjadikannya landasan sikap positif untuk saling mengerti dan memahami satu dengan lainnya.

Adapun kegunaan lain dari tulisan ini adalah memberikan sumbangan untuk menambah kekayaan khazanah ilmu pengetahuan di bidang keagamaan dalam kaitannya dengan penerapan sistem ekeonomi Islam yang tersembunyi di balik realitas kehidupan masyarakat di Indonesia, khususnya masyarakat Sulawesi Selatan. Kajian semacam ini pula sangat penting untuk menambah wawasan keilmuan khususnya bagi kalangan akademisi, sekaligus menjadi bahan renungan yang mendalami proses pembelajaran terhadap sejumlah eksistensi kemanusiaan secara lebih luas. Eksistensi manusia tesebut, baik menyangkut hubungan manusia dengan tuhan, manusia dengan sesama manusia serta manusia dengan alam sekitarnya guna kelangsungan kehidupan manusia itu sendiri.

Dalam tulisan ini, penulis lebih banyak mengarahkan analisis terhadap data kualitatif dengan menggunakan perspektif fenomenologis kemudian dianalisis sebagai pola implementasi sistem ekonomi bebrbasi komunitas. Sementara itu, data yang dibutuhkan menyangkut persoalan yang dialami dan dihadapi komunitas keagamaan An-Nadzir di Sulawesi Selatan, data yang diperoleh tidak ditempuh melalui prosedur statistik atau bentuk hitungan lainnya, tetapi diperoleh melalui pengamatan langsung, wawancara, dan diskusi dengan berbagai elemen masyarakat. Adapun tipe penelitian yang dilakukan yaitu descriptive-analysis, di mana penulis menelusuri fenomena penerapan sistem ekonomi Islam dengan pemberdayaan komunitas keagamaan jamaah An-Nadzir di Sulawesi Selatan.

An-Nadzir sebagai kelompok keagamaan non-mainstream muncul sebagai reaksi terhadap kegalauan akan hilangnya kepuasan spiritual dalam agama induk. Mereka lahir untuk mencari kepuasan spiritual dalam ber-agama dan mengejawantahkan dalam bentuk ritual 
baru. Salah satu aspek yang penting dari sosiologi agama adalah perhatiannya terhadap relasi antara realitas sosial dan agama. Sebagai kelompok keagamaan An-nadzir mengembangkan pemberdayaan komunitas Dalam kaitannya dengan pemberdayaan sosial-ekonomi yang dipraktikkan oleh An-Nadzir terdapat beberapa konsep pemberdayaan masyarakat yang telah dikemukakan oleh para ahli dalam menghadapi tantangan ekonomi global, tetapi di dalam tulisan ini hanya ingin mencoba menerapkan konsep pemberdayaan ekonomi masyarakat yang bersumber dari norma-norma keagamaan. Dalam hal ini norma agama diambil sebagai acuan utama dalam melakukan praktik sosial-ekonomi pada masyarakat.

James Coleman dalam rational choice theory ${ }^{11}$ menunjukkan ketika memberi contoh pengaruh doktrin Protestan terhadap sistem ekonomi, Ia menyatakan bahwa suatu norma atau doktrin keagamaan menjadi landasan dalam berprilaku seseorang ataupun kelompok. Norma yang sudah terserap dalam setiap individu/kelompok ini menjadi arahan untuk melakukan tindakan ekonomi. Tindakan-tindakan individu/kelompok yang berorientasi ekonomi ini selanjutya menghasilkan sistem ekonomi khusus. Demikian pula halnya analisis komunitas An-Nadzir di mana mereka melakukan tindakan ekonomi dilandasi dengan doktrin dan norma keagamaan. Mereka berangkat dari doktrin agama (Islam) yang menerapkan etika kenabian dalam rangka pemberdayaan sosial-ekonomi masyarakat, kemudian berproses hingga menjadikannya sebagai sistem perekonomian umat. Turner (1991) Mengemukakan bahwa kandungan ajaran agama bukan saja berupa doktrin melembagakan atau mendukung status quo (menghindari perubahan) tetapi juga dapat berupa doktrin yang justru memacu perubahan. ${ }^{12}$

Teori Coleman pada dasarnya menyatakan bahwa tindakan perseorangan mengarah pada suatu tujuan dan tujuan itu ditentukan oleh norma atau pilihan (preferensi). Aktor memilih tindakan yang dapat memaksimalkan kegunaan atau yang memuaskan keinginan dan kebutuhan mereka. Selain itu, sumber daya adalah sesuatu yang juga menarik perhatian yang dapat dikontrol. Ini pula tidak terlepas dari

\footnotetext{
11 James S Coleman, Rational Choice Theory, Advocacy and Critique. (London: Sage Publications 1992)

12 Sunyoto Usman. Pembangunan dan Pemberdayaan Masyarakat. (Yogyakarta: Pustaka Pelajar, 2008) h. 180
} 
kepercayaan (trust) masyarakat dengan sistem seperti ini, sebab dengan tindakan ekonomi yang berlandaskan norma agama yang identik dengan kejujuran bertindak, dapat mengurangi potensi kerugian.

Selain konsep tersebut, konsep Weber yang dikenal dengan sebutan "etika protestan (protestant etic, die protestantiche Ethic) dan hubungannya dengan "semangat kapitalisme" diambil pula sebagai acuan dalam menganalisa kehidupan sosial-ekonomi komunitas An-Nadzir. Tesis yang diperkenalkannya sejak tahun 1905 menyatakan bahwa ada hubungan antara ajaran agama dengan prilaku ekonomi. Hasil penelitian tersebut mengatakan bahwa orang-orang beragama (dalam hal ini agama Protestan) simetris dengan kedudukannya dalam bidang ekonomi. Terdapat korelasi positif antara orang beragama dan yang memiliki kecukupan ekonomi. Hal ini membuktikan bahwa semakin taat seseorang dalam melaksanakan perintah agama, maka semakin sejahtera pula kehidupan ekonominya. Tesis ini disinyalir berdasarkan pengamatan Weber terhadap fakta sosiologis yang ditemukannya di Jerman, bahwa sebagian besar pengusaha dan pemilik modal tingkat atas adalah orangorang Protestan.

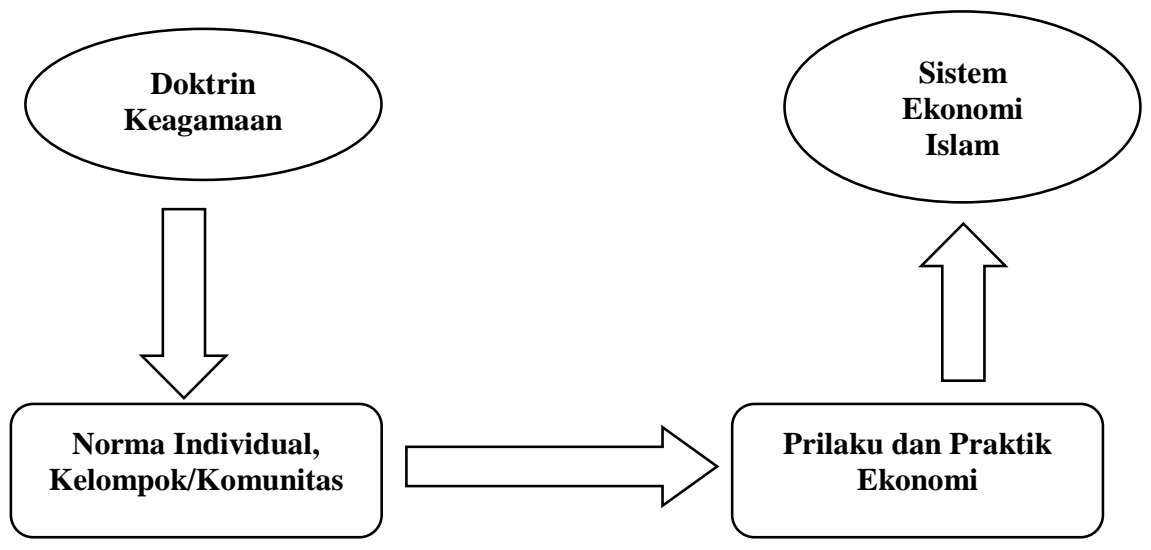

\section{B. An-Nadzir Sebagai Komunitas Keagamaan}

An-Nadzir merupakan sebuah kelompok gerakan keagamaan yang bermukim di wilayah Mawang, Kabupaten Gowa Propinsi Sulawesi Selatan. Secara harfiah, menurut ustadz Lukman ketika ditemui di perkampungan An Nadzir, kata An-Nadzir dari bahasa Arab yang berarti pemberi peringatan. Lukman merincikan, obyek yang diberi peringatan 
secara langsung adalah pengikut/jamaah An Nadzir yang tinggal di kampung Mawang. Sementara secara tidak langsung, memberi peringatan pada umat Islam pada umumnya. Jumlah pengikut An Nadzir saat ini, menurut Lukman, yang tersebar se-Nusantara berjumlah sekitar 10 ribu anggota. Belum termasuk yang ada di Singapura dan Malaysia. Jumlah yang ada di lingkungan Mawang, Kec. Bontomarannu, kabupaten Gowa, berjumlah sekitar 900 anggota atau sebanyak 140 kepala keluarga. Jamaah An-Nadzir secara formal memiliki badan hukum berupa yayasan yang berpusat di Jakarta, yang diketuai oleh Ir Lazuardi.

Jamaah An-Nadzir mulai berkembang di Indonesia beriringan dengan datangnya seorang da'i dari Malaysia, putera Dumai Pekanbaru. Pada tahun 1998, ia melakukan perjalanan dakwah ke berbagai daerah di Indonesia termasuk di Sulawesi Selatan, khususnya di Makassar dan di Luwu. Menariknya, kedatangan menjadi polemik di kalangan masyarakat Sulawesi Selatan, menyusul kesaksian sejumlah orang yang memandang sosok Syamsuri Madjid sebagai titisan Kahar Muzakkar, tokoh pejuang Islam di Sulawesi Selatan melalui gerakan Darul Islam/Tentara Islam Indonesia atau DI/TII. ${ }^{13}$

Kemampuan intelektual dan wawasan agama yang baik mampu menarik perhatian beberapa warga untuk menjadi pengikutnya dan membentuk Jamaah An-Nadzir dengan praktik ritual yang disebut dengan lathiful akbar. Sebagian besar pengikutnya adalah mereka yang percaya bahwa Syamsuri Madjid adalah Kahar Muzakkar, bahkan sebagai Imam Mahdi (hal ini akan dijelaskan pada bagian Tokoh/ Aktor Jamaah An-Nadzir).

Jamaah An-Nadzir mulai mengorganisir diri sebagai organisasi keagamaan pada tanggal 08 Pebruari 2003 di Jakarta dalam bentuk yayasan yang diberi nama Yayasan An-Nadzir. Sekretariat yayasan beralamat di Kompleks Nyiur Melambai, Jakarta Utara. Nama An-Nadzir yang berarti (pemberi) peringatan diberikan langsung oleh Syamsuri Madjid yang dalam jamaah dipanggil dengan sebutan "abah". Jamaah An-Nadzir mengklaim memiliki jaringan ke berbagai daerah di Indonesia, mulai dari Jakarta, Medan, Banjarmasin, Batam, Dumai, Batubara, Bogor, dan di berbagai daerah di Sulawesi Selatan.

An-Nadzir adalah organisasi atau yayasan yang berazaskan Alquran dan hadits Nabi Muhammad SAW. Bermaksud menghimpun

13 Anhar Gonggong. Abdul Qohhar Mudzakkar: Dari Patriot Hingga Pemberontak. (Yogyakarta: Ombak. 2004) 
potensi umat Nabi Muhammad SAW untuk mengangkat harkat dan martabat serta derajat sosial, ekonomi, akhlak, dan pendidikannya guna mencapai manusia yang tangguh, seimbang antara fikir dan zikir, jasmani dan rohani serta dunia dan akhirat. Yayasan ini memiliki visi terwujudnya insan kamil yang siddiq, amanah, tabligh, dan fathanah, menuju tatanan masyarakat yang adil dan makmur serta diridhai oleh Allah SWT dengan. ${ }^{14}$

Khusus di Sulawesi Selatan, perkembangan awal An-Nadzir dimulai di tanah Luwu. Terutama ketika Syamsuri Madjid masih eksis melakukan dakwah keagamaan di Luwu, pengikut An-Nadzir mulai berkembang di Kota Palopo dan beberapa tempat di Kabupaten Luwu. Namun, ketika kegiatan dakwah Syamsuri Madjid mulai jarang dilakukan, bahkan setelah ia meninggal dunia pada tahun 2006, jamaah An-Nadzir di Luwu mengalami tekanan dan stagnan. Puncaknya, ketika pemerintah daerah mengeluarkan surat keputusan untuk menghentikan segala bentuk aktivitas An-Nadzir di tanah Luwu dengan berbagai pertimbangan

Sepeninggal Syamsuri Madjid pada tahun 2006, Ustadz Rangka ${ }^{15}$ berinisiatif membentuk perkampungan An Nadzir di Kampung Mawang. Dibandingkan jamaah An Nadzir yang ada di tempat lain, di kampung Mawang merupakan format perkampungan yang paling lengkap seIndonesia. Di perkampungan ini, mereka tinggal di rumah pondok yang terbuat dari bambu dan beratap rumbia. Sebagian besar pengikut An Nadzir menggantungkan hidup dengan bertani dan memelihara ikan, dengan luas lahan garapan mencapai 8 ha untuk perikanan dan 10 ha untuk pertanian. Hasil pertanian dan perikanan kemudian dikumpulkan di Baitul Maal yang keuntungannya akan dibagikan secara adil pada setiap anggota jamaah.

Jamaah An-Nadzir memilih membentuk perkampungan yang jauh dari keramaian kota, dengan alasan agar lebih leluasa dan tenang dalam melaksanakan perintah Allah dan menjadi ahlul bait Nabi Muhammad secara utuh. Mereka memiliki keyakinan tanda-tanda akhir zaman akan

\footnotetext{
14 Ramlah Hakim. "Faham Lathiful Akbar An-Nadzir" dalam Kadir Ahmad (ed.,) Varian Gerakan Keagamaan. (Makassar: Balai Penelitian dan Pengembangan Keagamaan Agama Makassar. 2007)

${ }^{15}$ Ustadz atau Daeng Rangka merupakan salah satu tokoh utama dan pemimpin spiritual Komunitas An-nadzir yang bermukim di wilayah Mawang, Kabupaten Gowa, Sulawesi Selatan
} 
segera tiba. Di antara tanda akhir zaman yang disebut oleh Rasulullah, adalah dengan umatnya akan terasing dari umat manusia lainnya. AnNadzir juga memiliki pegangan hadis Nabi yang menyatakan bahwa kemunculan 313 orang yang memurnikan Islam dari belahan Timur, di mana dalam analogi An-Nadzir belahan Timur yang dimaksud adalah daerah Mawang yang mereka tempati (wawancara Ustadz Lukman, 2015). ${ }^{16}$

Jamaah An-Nadzir dengan ciri tampilan yang unik mudah dikenali secara luas oleh masyarakat. Penampilan khas dan unik dari kaum pria jamaah An Nadzir ini adalah kostum jubah sepaket sorban, dan rambut yang dipanjangkan sebahu serta diwarnai atau pirang dengan warna kuning keemasan, memakai celak mata, dan wewangian. Untuk kaum wanita An Nadzir menggunakan jilbab besar disertai kain cadar penutup muka dan juga memakai celak. Ustadz Lukman menegaskan bahwa memanjangkan rambut dan diberi pewarna sesuai dengan beberapa referensi hadis Rasulullah; "Untuk menjadi ahlul bait Rasulullah harus mengikuti hidup rasulullah secara keseluruhan".

\section{Penguatan Sistem Ekonomi Islami dengan Pemberdayaan Ekonomi Kreatif}

Pada awalnya, Komunitas An-Nadzir lebih banyak bergerak di bidang pertanian dan pertambakan. Tanah luas yang dimiliki oleh Daeng Rangka merupakan pondasi untuk bertani kebun dan tambak air tawar. Mereka kemudian mengembangkan sistem mina, yaitu sistem tanaman padi diselingi dengan tambak ikan mas. Sejauh ini usaha mereka cukup berhasil. Pemerintah kabupaten Gowa memberi apresiasi yang tinggi dengan menghadiri pesta panen Komunitas ini. Dinas perikanan Kabupaten Gowa pun ikut memberi perhatian dengan menghibahkan bibit ikan mas untuk dikelola. Bahkan gubernur pun menyempatkan diri datang dan memberi bantuan bibit ikan. Komunitas An-Nadzir dianggap berhasil membuat lahan tidur (di Desa Mawang) menjadi lahan produktif. $^{17}$

\footnotetext{
16 Ustadz Lukman merupakan pimpinan kedua Komunitas An-Nadzir dan biasanya menjadi juru bicara An-Nadzir dalam bidang agama, ekonomi dan sosial. Hal ini disebabkan karena beliau memiliki latar belakang pendidikan tinggi dan memiliki perusahaan swasta.

${ }^{17}$ Sebelum Komunitas An-Nadzir mendiami wilayah sekitar Danau Mawang, tempat ini dulunya dikenal sebagai hutan yang sangat jarang penduduknya. Di samping karena dianggap jauh dari pusat kehidupan masyarakat, juga karena dianggap sebagai sarang
} 
Komunitas An-Nadzir bukan merupakan komunitas yang tidak peduli terhadap urusan ekonomi. Meskipun komunitas ini lebih dikenal sebagai komunitas keagamaan, tetapi mereka sangat memperhatikan kehidupan sosial-ekonomi masyarakat. komunitas ini menyadari bahwa ekonomi adalah basis yang sangat penting bagi perkembangan dan keberlangsungan kehidupan suatu komunitas dalam masyarakat. Tanpa landasan ekonomi yang kuat tentu mereka akan goyah sebagai Komunitas yang utuh. Apalagi sebagian besar Komunitas An-Nadzir adalah kelompok pendatang dari berbagai daerah. Kedatangan mereka tidak membawa apa-pun. Seluruh aktivitas ekonomi mereka sebelumnya telah ditinggalkan dan berkumpul di Lingkungan Mawang. Tentu saja, mereka harus berupaya keras untuk memenuhi kebutuhan hidup mereka sehari-hari.

Sistem ekonomi berbasis syariah merupakan pilihan utama jamaah An-Nadzir dalam menjalankan bisnisnya, selain karena ingin menjalankan syariah Islam juga ingin melakukan perlawanan terhadap sistem ekonomi kapitalis yang dianggap merusak tatanan nilai masyarakat Islam. Semangat perlawanan terhadap sistem kapitalis terlihat pada komentar Ustadz Arif,

Sebenarnya ruang lingkupnya kami di sini adalah jamaah. Jadi, setiap orang yang bekerja di sini hanya untuk kepentingan jamaah dengan tujuan itu adalah menjadi uswatun khasana, sebagai contoh dimana hari ini begitu rusaknya sistem dunia, mana ada yang benar, semua yang dilarang oleh Allah dilanggar, ekonomi yang dibangun sekarang ini adalah sitem ekonomi kapitalis yang riba, inilah yang kami ingin buktikan bahwa tanpa sistem seperti itu ada juga kehidupan yang bisa berjalan, maknanya disini yang kita bangun adalah perkara yang hak, alhamdulillah pelan-pelan Allah memang bangkitkan karena pasti Allah akan bangkitkan itu kebenaran di akhir zaman, jadi saat ini memang untuk Komunitas tapi secara tidak langsung memang sudah keluar gaunnya, maknanya penduduk sekitar sini terutama petani, mereka ikut memanfaatkan kita untuk kerja, memanen sawah, menanam sawah, karena awalnya kami memang bekerja hanya unuk membantu tanpa mengharap dan menentukan imbalan kecuali mereka sendiri yang

kawanan perampok. Akibatnya, penduduk jarang sekali mau membuka lahan di sekitar Danau Mawang. Semuanya berubah sejak kehadiran Daeng Rangka (pimpinan annadzir) dan Komunitas An-Nadzirnya di tempat itu. 
memberi. Sekarang Alhamdulillah banyak sekarang petani itu menunggu kami untuk membeli (wawancara, 22 Oktober 2016).

Dengan pengelolaan usaha ekonomi mikro yang kreatif itu, Komunitas An-Nadzir dapat menghidupi Komunitas mereka, dapat menjalankan misi mereka untuk memberi peringatan kepada manusia akan kebenaran, tidak hanya melalui perkataan dan tabligh, tetapi juga melalui praktik sosial-ekonomi. Dalam hal ini, An-Nadzir berhasil melakukan pendekatan persuasif dengan masyarakat sekitar melalui penerapan sistem ekonomi islam. Di mana dalam praktiknya tidak hanya mengedepankan keuntungan ekonomi semata, tetapi lebih ditekankan pada sistem perdagangan yang berasaskan kejujuran. Hal inilah yang menjadikan An-nadzir tetap eksis dan dapat diterima dengan baik di tengah masyarakat Sulawesi Selatan.

Dengan implementasi sistem ekonomi Islam yang dipraktikkan oleh Komunitas An-Nadzir, menjadikan mereka berhasil dan mampu keluar dari logika kehidupan modern dan merancang sendiri format kehidupan mereka yang berbasis pada ajaran agama yang juga berbeda dengan mainstream ajaran Islam di Indonesia. ${ }^{18}$ Para pemimpin AnNadzir berhasil meyakinkan pengikutnya bahwa ajaran yang mereka perpegangi tidak hanya berisi tentang wacana keagamaan, tetapi juga rekonstruksi kehidupan sosial yang dicita-citakan sesuai dengan ajaran Nabi Muhammad.

\section{Implementasi Nilai dan Etika dalam Pemberdayaan Masyarakat}

Mendefinisikan nilai ataupun etika bukanlah perkara yang mudah. Nilai (value) berasal dari bahasa Latin velere yang artinya "menjadi kuat", atau "menjadi terhormat ${ }^{19}$. Untuk menjadi terhormat, diperlukan suatu pedoman perilaku yang dianggap baik. Oleh sebab itu, nilai dikaitkan dengan sesuatu yang baik (good) atau buruk (bad). Pada dasarnya, nilai memiliki pengertian yang berbeda-beda disesuaikan

\footnotetext{
${ }^{18}$ Mustaqim Pabbajah, Gerakan Islam Non-mainstream di Indonesia, Studi tentang Komunitas An-nadzir di Sulawesi Selatan. Jurnal Pemikiran Islam Alfikr. Vol. 2. No. 2. 2012.

19 Frederic G Reamer, Social Work Values and Ethics. Edisi kedua. (New York: Columbia University Press 1999) h.10
} 
dengan konteksnya. Soetarso ${ }^{20}$ mengemukakan bahwa nilai adalah kepercayaan, pilihan, atau asumsi tentang yang baik untuk manusia. Nilai bukan menyangkut keadaan dunia ini atau apa yang diketahui pada saat ini, tetapi bagaimanakah seharusnya atau sebaiknya dunia ini. Sarah Banks $^{21}$ mengungkapkan dalam kehidupan sehari-hari, nilai dapat berarti agama, politik atau prinsip-prinsip ideologi, keyakinan atau sikap.

Apabila dikaitkan dengan pemberdayaan masyarakat, maka nilai yang dimaksud di sini adalah seperangkat prinsip etik/moral yang fundamental di mana pekerja sosial berkomitmen. Misalnya, dalam pemberdayaan masyarakat ada nilai untuk menghargai keunikan dan perbedaan, privacy, menjaga kerahasiaan dan perlindungan. Dari sini dapat dipahami bahwa nilai berfungsi sebagai panduan perilaku seseorang, karenanya, nilai menyangkut sesuatu yang abstrak dan implisit. Secara singular nilai berada dalam pikiran manusia, nilai tersebut membentuk kepercayaan dan sikap seseorang, selanjutnya kepercayaan dan sikap tersebut membentuk nilai. ${ }^{22}$

Nilai merupakan suatu keyakinan yang bersifat abstrak. Sesuatu yang abstrak dan implisit ini dipraktikkan oleh prilaku etik yang besifat kongkret dan eksplisit. Oleh sebab itu, peranan nilai dalam hal ini bersifat sangat fundamental dalam perilaku seseorang maupun perilaku kelompok dalam pekerjaan sosial. Karena nilailah yang menuntun, menggerakkan dan sebagai pemberi petunjuk antara kebenaran dan kesalahan dalam melakukan pekerjaan sosial. Tanpa nilai, perilaku seseorang atau kelompok tidak memiliki pedoman tentang baik buruk dan tentu saja benar atau salah. Di sisnilah peran penting nilai dan etika dalam pemberdayaan sosial.

Dalam kaitannya dengan Komunitas An-Nadzir, peranan nilainilai Islam dan etika kenabian sangat penting dalam pelaksanaan suatu pekerjaan sosial-ekonomi. Mereka menjadikan keduanya sebagai sebagai fondasi pengetahuan mendasar yang harus dimiliki oleh setiap anggota komunitas dalam praktik pekerjaan sosial maupun ekonomi. Nilai dan etika kenabian dijadikan landasan berpikir, kemudian dikejawantahkan dalam praktik sosial ekonomi. Keyakinan tentang nilai Islam yang benar

\footnotetext{
${ }^{20}$ Soetarso. Praktik Pekerjaan Sosial. Jilid I. (Bandung: Sekolah Tinggi Kesejahteraan Sosial 1968) h.32-35

${ }^{21}$ Sarah Banks. Ethics and Values in Social Work. (New York: Palgrave, 2001) h.6

${ }^{22}$ Miftachul Huda. Pekerjaan Sosial dan Kesejahteraan Sosial. (Yogyakarta: Pustaka Pelajar, 2009) h.136.
} 
juga berperan sebagai petunjuk bagi pekerja sosial untuk memutuskan suatu perkara ketika terjadi dilema etis, maka ketika dilema ini terjadi, nilai tersebut sangat diperlukan untuk membuat keputusan etik yang tepat.

Salan satu nilai Islam yang menarik yang diterapkan Komunitas An-Nadzir dalam praktik jual-beli adalah kejujuran (As-Shidq). Mereka sangat mengedepankan kejujuran dan sedikit banyaknya meniru cara Nabi Muhammad SAW dalam melakukan perdagangan. Misalnya, jika mereka menjual sayur, dijelaskan terlebih dahulu bahwa sayur ini dipetik hari ini harganya sekian, sayur ini dipetik kemarin harganya sekian. Begitu pula dengan timbangan, mereka lakukan dengan sejujur-jujurnya. Hal itu yang mendorong sebagian petani di sekitar Mawang mau menjual gabah mereka kepada An-Nadzir meski harga pembeliannya lebih rendah dari harga yang ditetapkan oleh pembeli gabah di luar. Hal ini sebagaimana diutarakan oleh Daeng Rangka dalam sebuah kesempatan wawancara,

Banyak itu dik yang jual gabahnya sama kami padahal pembelian kami $\mathrm{Rp}$ 2250-2300, tengkulak diluar sana $\mathrm{Rp} 2500$ tapi mereka pada kesini, saya bilang kenapaki mau jual sama saya, mereka bilang tidak apa-apaji ustadz. Tapi memang dalam menakar kami betul-betul seimbangkan itu timbangan tidak seperti tengkulak diluar sana (wawancara, Oktober 2016).

Hal ini menunjukkan bahwa An-Nadzir sangat memeprthatikan nilai Islam dalam praktik sosial-ekonomi. Nilai kejujuran itu yang diperpegangi oleh semua anggota komunitas, sehingga mereka diberikan kepercayaan oleh masyarakat. Selain itu, nilai Islam yang lain yang dipraktikkan adalah adil dan amanah. Komunitas An-nadzir dalam bekerjasama dengan masyarakat sekitar sekitar sangat menjunjung tinggi sikap amanah dan prinsip keadilan. Apabila diberi kepercayaan oleh masyarakat dalam pengelolaan sawah, kebun dan lain sebagainya mereka mengelola dengan profesional dan bagi hasil yang saling menguntungkan.

\section{E. Implementasi Nilai Islam dan Kenabian dalam Etos Kerja}

Agama adalah sesuatu yang inherent dalam kehidupan manusia. Terlepas dari "jenis" agama yang dianut, manusia pada prinsipnya 
memegang kepercayaan tertentu sebagai bukti terikatnya manusia pada sesuatu yang "maha". Di sisi lain aktivitas pemenuhan kebutuhan hidup adalah sebuah keniscayaan. Secara naluriah, manusia dituntut untuk dapat survive dalam hidup dengan melakukan aktivitas ekonomi. Dalam hal ini, terdapat hubungan antara agama sebagai keyakinan dengan etos kerja untuk survive dalam kehidupannya. Atau, agama dan etos kerja dalam ekonomi adalah dua hal yang berbeda, keduanya berjalan pada "relnya" masing-masing.

Dalam konteks Islam, apakah masyarakat yang mempunyai identitas keislaman yang baik akan berpengaruh terhadap kegairahannya dalam melakukan aktivitas ekonomi? Dengan bahasa yang lebih sederhana, apakah seseorang yang beragamanya baik akan menghasilkan etos kerja yang baik pula. Sebaliknya, seseorang yang "defisit" keagamaannya akan menjadikan defisit semangat kerja atau kegairahan ekonomi. Dengan bahasa yang ekstrim, bagaimana hubungan agama yang "lebih" kepada spritualitas (ruhani) dengan sistem prilaku ekonomi yang "lebih" kepada keduniaan (materi).

Masalah etos kerja memang cukup rumit, nampaknya tidak ada teori tunggal yang dapat menerangkan segala segi gejalanya, juga bagaimana menumbuhkan dari yang lemah kearah yang kuat atau lebih baik, kadang-kadang nampak bahan etos kerja dipengaruhi oleh system kepercayaan, seperti agama, kadang-kadang nampak seperti tidak lebih dari hasil tingkat perkembangan ekonomi tertentu masyarakat saja. Kesan bahwa etos kerja terkait dengan system kepercayaan diperoleh karena pengamatan bahwa masyarakat tertentu dengan system kepercayaan tertentu memiliki etos kerja lebih baik (atau lebih buruk) dari pada masyarakat yang lain, dengan system dasar apa yang terkenal dengan "Etika Prostestan", persis peneliti yang lain juga melihat gejala yang sama pada masyarakat dengan system kepercayaan yang berbeda seperti masyarakat Tokugawa di Jepang (Robert N. Bellah) di Jawa (Geertz) dan Hindu Barhmana di Bali (Geertz) atau Ismaili di Afrika Timur.

Kesan bahwa etos kerja terkait dengan tingkat perkembangan ekonomi tertentu juga merupakan hasil pengamatan terjadap masyarakat tertentu yang etos kerjanya menjadi baik setelah mencapai kemajuan ekonomi pada tarap tertentu. Seperti umumnya negara-negara industri baru di Asia Timur, yaitu Korea Selatan, Taiwan, Hongkong dan Singapura, kenyataan bahwa masyarakat Singapura misalnya menunjukkan etos kerja negaranya setelah mencapai tingkat 
perkembangan ekonomi yang cukup tinggi. Peningkatan etos kerja di sana kemudian mendorong laju perkembangan yang lebih cepat lagi, sehingga kota itu menjadi seperti sekarang.

Berbicara tentang etos kerja dalam hubungannya dengan implementasi ekonomi Islam yang dipraktikkan oleh An-Nadzir, di sini digunakan dasar pemikiran bahwa Islam sebagai suatu sistem keimanan, yang tentunya mempunyai pandangan tertentu yang positif terhadap masalah etos kerja. Relevansi pembicaraan ini kepada masalah pemberdayaan sosial-ekonomi umat Islam ialah kenyataan bahwa sebagian besar rakyat Indonesia beragama Islam, jadi suatu pendekatan dari sudut keislaman dapat diharapkan dapat mempunyai dampak yang berlangsung pada masalah etos kerja itu, jika memang pada masalah etos kerja ini ada masalah, karena agama bertitik tolak dari keimanan, maka setiap percobaan suatu masalah dari sudut pandangan keagamaan juga bertitik tolak dari keimanan, maka etos kerja dalam Islam adalah hasil suatu kepercayaan seorang muslim, bahwa kerja mempunyai kaitan dengan tujuan hidupnya, yaitu memperoleh perkenan Allah SWT, berkaitan dengan ini kita dapat menegaskan kembali Islam agama amal atau kerja (praktis). Inti ajarannya ialah bahwa hamba mendekati dan berusaha memperoleh ridha Allah melalui kerja atau amal sholeh dan dengan memurnikan sikap penyembahan hanya kepada-Nya.

Etos kerja yang dipraktikkan oleh An-Nadzir merupakan kewajiban bagi semua manusia yang ada di dunia ini untuk mengelola alam beserta isinya, hal ini sebagaimana petikan wawancara dengan ustadz lukman, mengatakan bahwa;

Kami mengelola tanah ini, betul-betul karena mengharap ridha Allah, dalam keyakinan saya, bahwa jika kita mengelola bumi ini karena kita sebagai khalifah, InsyaAllah kita akan dapat berkah dan rahmat dari Allah, yang jelas bumi beserta isinya ini untuk digarap, kita bekerja bukan untuk kepentingan ekonomi saja tapi yang paling utama adalah mengharap ridha dari Allah (wawancara, November 2016).

Berbicara tentang etos kerja muslim, apalagi dipertajam dengan frasa "perspektif kultural", tidak terlepas dari paradigma hubungan antara "agama" dan "masyarakat pemeluk" dari agama yang bersangkutan. Karena dalam pembahasan ini dibatasi di kalangan komunitas "muslim". Maka tentu saja masalah etos tersebut perlu dibaca hubungan korelasi antara "agama Islam" di satu sisi dan "umat Islam (muslim)" di sisi yang 
lain. $^{23}$ Tetapi berlawanan dengan itu semua, secara empirik sering dikemukakan penilaian negatif bahwa umat Islam menderita penyakit fatalisme atau paham nasib, yang kemudian membuat mereka pesimistis dan "nrimo ing pandum", jelas sekali bahwa membuat generalisasi itu keliru. Hanya saja dalam rangka polemik klasik atau paham "Jabbariyah", (predetermenisme) dan "Qadariyyah" (kebebasan manusia) yang banyak di kalangan Islam masih berlangsung sekarang.

Sikap-sikap yang mengarah pada paham jabbariyah memang sering ditemukan, dengan kata lain di masyarakat kita mempunyai potensi fatalisme. Sebagaimana telah disinggung semula berkenaan dengan masalah kontroversi "takdir", dan "ihktiar", dalam hal ini penting sekali kita telaah bahwa sesungguhnya firman Allah yang dijadikan acuan atau paham takdir atau ketentuan nasib (predeterminisme) adalah berbicara pada hal yang telah terjadi (last) pada seorang manusia baik, atau buruk dan diharapkan dapat menerimanya dengan ikhlas terhadap apa yang telah terjadi tanpa ada rasa penyesalan. Sedangkan untuk hal yang belum terjadi, maka sikap yang dianjurkan bukanlah kefasipan dari segala kemungkinan yang terjadi. Demi mencapai tujuan yang baik, pribadi yang beriman dan bertaqwa harus menyiapkan diri untuk hari esok yang lebih lebih baik. Realitas pemberdayaan sosial-ekonomi yang dilakukan oleh komunitas An-Nadzir, secara normatif sesungguhnya hubungan dan peran agama terhadap etos kerja merupakan sesuatu yang integral. Hubungan agama dengan etos kerja, ibarat bensin dengan mobil. Agama tidak hanya mampu mempengaruhi etos kerja menjadi lebih baik, tetapi agama justru menjadi bahan bakar dan sumber etos kerja tersebut.

Keberhasilan jamaah An-Nadzir di bidang pertanian kemudian mendorong masyarakat setempat menyerahkan tanahnya untuk dikelola dengan sistem bagi hasil. Sistem bagi hasil dalam mekanisme An-Nadzir biasanya dilakukan dengan sistem bagi dua, seperti yang dijelaskan oleh Daeng Rangka,

Misalkan adik punya sebidang tanah tapi saya yang garap, hasilnya itu dibagi dua, cuman kami ini lebih dulu menyerahkan hasil panen kepada pemilik tanah dan biarkan mereka yang bagi sendiri kepada kami, sebab kami hindari sesuatu yang riba (wawancara, Oktober 2016).

${ }^{23}$ H. A. Mukti Ali. Agama dan Pembangunan di Indonesia, Jilid VI. (Jakarta: Biro Humas Departemen Agama RI, 1975) h. 44 
Penjelasan Daeng Rangka tersebut menunjukkan bahwa sistem bagi dua yang dilakukan oleh An-Nadzir diserahkan sepenuhnya kepada pemilik tanah, dan membiarkannya membagikan kepada jamaah AnNadzir. Hal ini dimaksudkan untuk menghindarkan kecurigaan dari pemilik tanah dan sekaligus untuk transparansi aktivitas perdagangan. Jamaah An-Nadzir mengedepankan sikap kejujuran dan keterbukaan. Hal ini mendorong warga senang bekerjasama dengan jamaah An-Nadzir. Hingga saat ini, jamaah An-Nadzir telah mengelola sekitar 40 ha tanah pertanian untuk padi, ubi, dan komoditas lainnya. Sebanyak 20 ha di antaranya adalah tanah pertambakan.

Dalam konteks pemberdayaan sosial-ekonomi yang dipraktikkan komunitas An-Nadzir, kesejahteraan sosial dapat dimaknai sebagai terpenuhinya kebutuhan seseorang, kelompok, atau masyarakat dalam hal material, spiritual maupun sosial. Kemuliaan seorang manusia itu bergantung kepada apa yang dilakukannya. Dengan itu, komunitas AnNadzir berkeyakinan bahwa dengan melakukan sesuatu amalan atau pekerjaan yang mendekatkan seseorang kepada Allah adalah sangat penting serta patut untuk diberi perhatian. Amalan atau pekerjaan yang demikian selain memperoleh keberkahan serta kesenangan dunia, juga ada yang lebih penting yaitu merupakan jalan atau tiket dalam menentukan tahap kehidupan seseorang di akhirat kelak; apakah masuk golongan ahli surga atau sebaliknya, sebagaimana hasil perbincangan dengan ustadz Arif yang mengatakan bahwa;

Kita bekerja di sini, tidak mengejar kepentingan dunia, tapi yang kita lakukan adalah bagaiamana kiat sebagai hamba Allah menjadi orang yang bermanfaat bagi alam dan masyarakat sekitar, sehingga kita hanya berharap kepada Allah yang membalasnya bukan manusia.

Istilah 'kerja' dalam pandangan komunitas An-Nadzir bukanlah semata-mata merujuk kepada mencari rezeki untuk menghidupi diri dan keluarga dengan menghabiskan waktu siang maupun malam, dari pagi hingga sore, terus menerus tak kenal lelah, tetapi kerja mencakup segala bentuk amalan atau pekerjaan yang mempunyai unsur kebaikan dan keberkahan bagi diri, keluarga dan masyarakat sekelilingnya serta negara. Dengan kata lain, orang yang berkerja adalah mereka yang menyumbangkan jiwa dan tenaganya untuk kebaikan diri, keluarga, masyarakat dan negara tanpa menyusahkan orang lain.

Oleh karena itu, kategori ahli Surga seperti yang digambarkan dalam Al-Qur'an bukanlah orang yang mempunyai pekerjaan/jabatan 
yang tinggi dalam suatu perusahaan/instansi sebagai manajer, direktur, teknisi dalam suatu bengkel dan sebagainya. Tetapi sebaliknya Al-Quran menggariskan golongan yang baik lagi beruntung (al-falah) itu adalah orang yang banyak taqwa kepada Allah, khusyu sholatnya, baik tutur katanya, memelihara pandangan dan kemaluannya serta menunaikan tanggung jawab sosialnya seperti mengeluarkan zakat dan lainnya (QS Al Mu'minun: $1-11){ }^{24}$

Etos kerja Islami yang dipraktikkan An-Nadzir dalam praktik pemberdayaan sosial-ekonomi bersumber dari ajaran wahyu yang dapat dicerna akal. Al-Quran sebagai sumber pedoman hidup dan menjalankan Sunnah Rasul sangat kuat pengaruhnya bagi umat untuk meningkatkan etos kerja. Dalam Islam manusia diperintahkan untuk melakukan amalamal konkrit, baik bersifat suruhan tegas, maupun rangsangan motivasi untuk bekerja. Larangan tegas terhadap sifat malas, meminta-minta, melacur, berjudi, mengambil hak orang lain menunjukkan tidak ada pilihan lain bagi orang yang mengaku Islam untuk tidak mempunyai etos kerja. Demikian juga halnya dengan komunitas An-Nadzir yang menganjurkan dan memotivasi umat Islam untuk bekerja dengan harapan mendapat keridhaan Allah. Dengan asumsi ini, cukup jelas bahwa secara normatif dan empiris, kesalehan sosial dapat mempengaruhi produktivitas ekonomi dan prilaku sosial selama ajaran agama dipahami dan dilaksanakan secara menyeluruh dalam rangka terciptanya masyarakat mandiri serta terwujudnya kesejahteraan sosial.

\section{F. Kesimpulan}

Komunitas keagamaan An-nadzir yang bermukim di Sulawesi Selatan merupakan komunitas keagamaan yang mengemplementasikan nilai-nilai islam dalam kehidupan bermasyarakat, baik itu ekonomi maupun sosial. Komunitas keagamaan an-Nadzir dapat dikategorikan sebagai komunitas yang mempraktikkan pemberdayaan sosial-ekonomi yang lebih mandiri. Pemberdayaan yang berusaha menghidupkan dan mengimplementasi kehidupan kenabian dalam aktivitas sosial-ekonomi, meskipun hingga saat ini kesalehan komunitas masih diutamakan. Gerakan keagamaan semacam ini merupakan fakta dan realitas dunia saat ini telah jauh dari model masyarakat yang dicitacitakan oleh Nabi Muhammad. Karena itu, mereka berupaya mengembalikan semangat

${ }^{24}$ Al-Quran Surah Al Mu'minun. h. 1-11 
kenabian tersebut dalam kehidupan sosial ekonomi. Menurut komunitas An-Nadzir, hanya dengan membangkitkan kembali semangat kenabian, persoalan besar yang dihadapi oleh manusia akan dapat teratasi. Membangkitkan semangat kenabian tidak hanya bermakna simbolik, tetapi juga diterjemahkan dalam bentuk nyata terutama tampilan fisik dan praktik sosial-ekonomi.

Komunitas keagamaan an-Nadzir lebih terfokus pada revitalisasi semangat kenabian dalam komunitas mereka. Dengan kata lain, sifat mereka cenderung ekslusif tetapi tetap terbuka. Mereka eksklusif dalam hal ajaran agama. Tidak ada dialog untuk persoalan keagamaan, tetapi terbuka dalam hubungan ekonomi dan sosial. Oleh karena tidak bersifat ekspansif, maka benturan antara kelompok an-Nadzir dengan masyarakat atau dengan organisasi lain dapat terhindarkan. Komunitas an-Nadzir dapat menerima dan diterima baik oleh orang di lingkungan masyarakat sekitar Mawang, karena mereka membuka diri kepada masyarakat sekitar terutama di sektor ekonomi dengan jalur pemberdayaan. Anggota komunitas an-Nadzir banyak menjadi tenaga kerja di kebun dan sawah milik masyarakat lokal. Mereka memiliki pelanggan bengkel, pembeli di pasar, pengisian ulang air galon, cuci motor dari masyarakat luar.

Implementasi sistem ekonomi Islam yang dipraktikkan komunitas keagamaan an-Nadzir lebih berorientasi pada kesalehan sosial dan keselamatan individual dalam rangka tercapainya dan terciptanya kesejahteraan sosial. Oleh karena itu, menegakkan syariat dan hukum Allah harus dimulai dari masing-masing individu dan kelompok sebagai kunci kesejahteraan. Berdasarkan hal tersebut mereka tidak mengganggap pendirian negara Islam sebagai sesuatu yang penting. Dalam hal ini, sikap anti pendirian negara Islam merupakan sikap positif dari gerakan kegamaan An-Nadzir. Mereka tidak menjadikan pendirian negara Islam sebagai agenda perjuangan, sebab itu mereka menolak penggunaan jalur politik, tetapi mereka lebih menitikberatkan nilai Islam pada kepentingan sosial-ekonomi. Perjuangan penegakan Syariat Islam adalah perjuangan individual karena keselamatan akhirat memang bersifat nafsi-nafsi atau individual. Selain itu, gerakan Komunitas ini bersifat pasif dan lebih berorientasi pada kesalehan Komunitas. Sifat pasif ini menyebabkan benturan dengan masyarakat tidak terjadi karena mereka tidak mengkampanyekan ajaran dan pemahaman mereka kepada masyarakat umum.

Sebagai sebuah komunitas keagamaan, An-Nadzir telah melakukan sesuatu yang positif. Mereka mampu mengembangkan 
kemampuan ekonomi yang berbasis pada ekonomi kreatif, misalnya pengelolaan pertanian dengan sistem mina, perikanan, perkebunan, bengkel dan cucian motor serta membuat pasar sendiri untuk meperjual belikan hasil pertanian, perkebunan dan perikanan mereka. Selain itu, komunitas An-Nadzir juga membantu masyarakat sekitar untuk melakukan pengelolaan tanah tanpa berupaya menjadikan masyarakat tersebut sebagai bagian dari komunitas mereka. Dalam hal ajaran agama, mereka bersifat pasif. Mereka terbuka dan menerima siapapun yang datang berkunjung, bertamu, dan bertanya tentang pemahaman keagamaan mereka, tetapi mereka tidak ingin melakukan dialog kebenaran, karena mereka telah meyakini bahwa kebenaran yang mereka pegangi adalah kebenaran yang sesungguhnya.

\section{Daftar Pustaka}

Ali, H. A. Mukti. 1975. Agama dan Pembangunan di Indonesia, Jilid VI. Jakarta: Biro Humas Departemen Agama RI.

Banks, Sarah. 2001. Ethics and Values in Social Work. New York: Palgrave.

Budiharsono, Sugeng, 2004, Strategi Penanggulangan Kemiskinan Nasional, TKP3KPK, Menko Kesra, Jakarta

Coleman, James S. 1992. Rational Choice Theory, Advocacy and Critique. London: Sage Publications.

Giddens, Anthony. 2010. Teori Strukturasi, Dasar-dasar Pembentukan Struktur Sosial Masyarakat. Yogyakarta: Pustaka Pelajar.

Gonggong, Anhar. 2004. Abdul Qohhar Mudzakkar: Dari Patriot Hingga Pemberontak. Yogyakarta: Ombak.

Hakim, Ramlah. 2007. "Faham Lathiful Akbar An-Nadzir" dalam Kadir Ahmad (ed.,) Varian Gerakan Keagamaan. Makassar: Balai Penelitian dan Pengembangan Keagamaan Agama Makassar.

Hikmat, Harry. 1999. "Pembangunan Sosial yang Berpusatkan pada Rakyat: Reorientasi Paradigma Pembangunan Kesejahteraan Sosial Pascakrisis". Makalah. Bandung: Unpad.

Hikmat, Harry. 2010. Strategi Pemberdayaan Masyarakat. Bandung: Humaniora Utama Press 
Huda, Miftachul. 2009. Pekerjaan Sosial dan Kesejahteraan Sosial. Yogyakarta: Pustaka Pelajar.

Kuntowijoyo. 2004. Islam sebagai Ilmu, Epistemologi, Metodologi, dan Etika, Jakarta: Penerbit Teraju.

Pabbajah, Mustaqim. 2012. Pemberdayaan Sosial-Ekonomi sebagai Strategi Penanganan Gerakan Keagamaan pada Kasus Jama'ah An-Nadzir di Kabupaten Gowa Sulawesi Selatan. Jurnal Multikultural dan Multireligius Harmoni Volume 11, Nomor 3. Jakarta: Balitbang Kemenag RI.

Pabbajah, Mustaqim 2012. Gerakan Islam Non-mainstream di Indonesia, Studi tentang Komunitas An-nadzir di Sulawesi Selatan. Jurnal Pemikiran Islam Alfikr. Vol. 2. No. 2. Makassar: Fakultas Ushuluddin UIN Alauddin.

Partoatmodjo, Sadji, 2004. Masalah Kemiskinan dan kompleksitas Penanggulangannya, TKP3KPK Menko Kesra, Jakarta

Rahardjo, Dawam. 1990. Etika Ekonomi dan Manajemen. Yogyakarta: PT Tiara Wacana.

Soetarso. 1968. Praktik Pekerjaan Sosial. Jilid I. Bandung: Sekolah Tinggi Kesejahteraan Sosial.

Soetomo. 2011. Pemberdayaan Masyarakat. Yogyakarta: Pustaka Pelajar

Turner, Brian S. 1991. Religion and Social Theory. London: Sage Publication.

Usman, Sunyoto. 2008. Pembangunan dan Pemberdayaan Masyarakat. Yogyakarta: Pustaka Pelajar.

Weber, Max. 1956. The Protestant Ethic and Spirit of Capitalism. New York: Charles Scribners Son.

Wrihatnolo, Randy R dan Riant Nugroho Dwidjowito. 2007. Manajemen Pemberdayaan: Sebuah Pengantar dan Panduan Untuk Pemberdayaan Masyarakat. Jakarta: Elex Media Komputindo. 